\title{
Mammary Epithelial Proliferation and Estrogen Receptor $\alpha$ Expression in Prepubertal Heifers: Effects of Ovariectomy and Growth Hormone
}

\author{
S. D. K. Berry, ${ }^{\star}$ P. M. Jobst, ${ }^{\star}$ S. E. Ellis, $\dagger^{\dagger}{ }^{1}$ R. D. Howard,† A. V. Capuco,‡ and R. M. Akers ${ }^{\star}$ \\ *Department of Dairy Science, Virginia Tech, Blacksburg 24061 \\ †Virginia-Maryland Regional College of Veterinary Medicine, Blacksburg 24061 \\ ¥Gene Evaluation and Mapping Laboratory, USDA-ARS, Beltsville, MD 20705
}

\section{ABSTRACT}

The objectives of this study were to determine the effects of ovariectomy and growth hormone on mammary epithelial cell proliferation and estrogen receptor $\alpha(\mathrm{ER} \alpha)$ expression within the bovine mammary gland. Two experiments were performed. In the first experiment, eight Holstein heifer calves aged between 1 and 3 mo were ovariectomized, while six calves served as controls. At 6 mo of age, calves were treated with bromodeoxyuridine (BrdU) to label proliferating cells and sacrificed $2 \mathrm{~h}$ later. Coinciding with reduced mammary mass ( $304 \pm 25$ vs. $130 \pm 21 \mathrm{~g}$ ), proliferation of mammary epithelial cells was significantly lower in ovariectomized heifers compared to control heifers (2.24 vs. $0.25 \%) \mathrm{ER} \alpha$ expression was restricted to mammary epithelial cells and was not observed within intra-lobular stroma of parenchymal tissue. The proportion of $\mathrm{ER} \alpha$ positive cells was significantly higher in ovariectomized heifers than in controls $(36.1 \% \pm 2.2$ vs. $46.7 \% \pm$ $2.4)$. In the second experiment, mammary biopsies were taken from five 6-mo-old heifers, immediately preceding and $7 \mathrm{~d}$ following a single injection of bovine growth hormone. Mammary epithelial cell proliferation (assessed by incorporation of ${ }^{3} \mathrm{H}$-thymidine) was increased by growth hormone. The proportion of $\operatorname{ER} \alpha$ positive mammary epithelial cells was not increased by growth hormone. In conclusion, reduced mammary epithelial cell proliferation following ovariectomy was associated with an increase in ER $\alpha$ expression, whereas increased proliferation caused by bovine growth hormone was not associated with changes in the proportion of $\mathrm{ER} \alpha$ positive cells.

(Key words: estrogen receptor $\alpha$, growth hormone, mammary, ovariectomy)

Abbreviation key: BrdU = bromodeoxyuridine, $\mathbf{E}=$ estrogen, $\mathbf{E R} \alpha=$ estrogen receptor $\alpha, \mathbf{G H}=$ growth

Received October 17, 2002.

Accepted December 6, 2002.

Corresponding author: R. M. Akers; e-mail: rma@vt.edu.

${ }^{1}$ Present address: Department of Animal and Veterinary Sciences, Clemson University, Clemson, SC 29634-0361. hormone, IGF-I = insulin like growth factor I, OVX = ovariectomized, $\mathbf{T D U}=$ terminal ductular unit.

\section{INTRODUCTION}

On a mass basis, the majority of bovine mammary development occurs during pregnancy, when mammogenic hormones such as growth hormone, estrogen, and progesterone stimulate proliferation of mammary epithelial cells and subsequent formation of mature alveoli (Topper and Freeman, 1980). However, an important aspect of bovine mammary development occurs earlier in life, between approximately 3 and 9 mo of age (Sinha and Tucker, 1968). During this prepubertal period, heifer mammary development is allometric, growing at a faster rate than the rest of the body, and expansion of ductal epithelial tissue provides a foundation for later development. Proper prepubertal mammary development in heifers is essential for reaching optimal mammary development and subsequent milk yield during future lactations. For example, raising heifers on a high rate of gain between 3 and 6 mo of age can impair mammary development and may result in reduced milk production during future lactations (Lammers et al., 1999; Sejrsen et al., 2000). Although the exact biological mechanisms underlying this phenomenon are not fully established, it is clear that manipulation of the mammary gland in the prepubertal heifer can impact subsequent milk yield. Consequently, detailed understanding of the mechanisms controlling cell proliferation within the heifer mammary gland will undoubtedly lead to novel techniques to enhance prepubertal mammary development and subsequent lactation.

Prepubertal mammary development is controlled through the combined actions of growth hormone (GH), estrogen $(\mathbf{E})$, and locally derived growth factors, such as insulin-like growth factor (IGF-I). In prepubertal heifers, allometric growth of the mammary gland is dependent on ovarian secretion(s): ovariectomy at 4 mo of age results in reduced mammary development at 9 mo of age (Purup et al., 1993). Exogenous GH and E both stimulate proliferation of mammary epithelial cells in pre- and postpubertal heifers (Woodward et al., 1993; 
Berry et al., 2001; Capuco et al., 2002). Despite its critical role in promoting prepubertal mammary development, the detailed cell biology of $\mathrm{E}$ action and $\mathrm{ER} \alpha$ expression within the mammary gland remain undefined.

There are two distinct forms of the estrogen receptor, $\mathrm{ER} \alpha$ and $\mathrm{ER} \beta$, which are each encoded by separate genes (Kuiper et al., 1996). Although mRNA for both $\mathrm{ER} \alpha$ and $\mathrm{ER} \beta$ have been detected in mammary tissue of mice (Couse and Korach, 1999; Saji et al., 1999) and humans (Jarvinen et al., 2000), mRNA for $\operatorname{ER} \beta$ is considerably less abundant than that of ER $\alpha$. In agreement with mammary expression of the two receptor subtypes, disruption of $\mathrm{ER} \alpha$ results in complete loss of postnatal mammary development and function (Korach, 1994), but disruption of $\operatorname{ER} \beta$ does not affect development of mammary epithelial or stromal tissue. In the rodent mammary gland, $\mathrm{ER} \alpha$ is distributed throughout epithelial and stromal tissues (Haslam, 1989), both of which are required for mammary development (Mueller et al., 2002). However, in ruminants, ER $\alpha$ expression is restricted to mammary epithelium (Capuco et al., 2002). The mechanism by which $\mathrm{ER} \alpha$ stimulates proliferation of mammary epithelial cells appears to be more complex than initially imagined, because most proliferating cells do not express ER $\alpha$ (Zeps et al., 1998; Capuco et al., 2000), suggesting that estrogen does not directly stimulate cell proliferation. Possibly, the ability of estrogen to stimulate mammary epithelial proliferation is regulated through $\mathrm{ER} \alpha$ localization throughout mammary epithelium as well as ER $\alpha$ activity and estrogenstimulated transcription of target genes. Hormonal regulation of $\mathrm{ER} \alpha$ expression in the bovine mammary gland has not been investigated but may be influenced by E or GH. Previous reports demonstrated that ovariectomy increased expression of uterine $\mathrm{ER} \alpha$ mRNA in rats (Rosser et al., 1993; Mohamed and Abdel-Rahman, 2000). Furthermore, mRNA expression levels in ovariectomized rats were returned to that of control animals by administration of $\mathrm{E}$. Administration of $\mathrm{GH}$ to virgin rats increased expression of ER mRNA in mammary tissue (Feldman et al., 1999), leading to the hypothesis that GH may act in part by enhancing the action of $\mathrm{E}$ via increased expression of ER $\alpha$. To further elucidate the role of ER $\alpha$ in stimulating prepubertal heifer mammogenesis, we were interested in determining whether mammary expression of $\mathrm{ER} \alpha$ was regulated by the ovary or by bovine $\mathrm{GH}$, and whether changes in ER $\alpha$ expression were also related to changes in proliferation of mammary epithelial cells. Consequently, the objectives of this experiment were to determine the effects of ovariectomy and bovine growth hormone on mammary epithelial proliferation and corresponding ER $\alpha$ expression in prepubertal heifers.

\section{MATERIALS AND METHODS}

\section{Experimental Design and Sampling}

All experiments were conducted with the approval of the Virginia Tech Animal Care committee (approval number 98-036-DASC). To test the effect of ovariectomy on mammary epithelial proliferation and $\mathrm{ER} \alpha$ expression, 14 newborn Holstein heifer calves were assigned to one of two treatments: control $(n=6)$ or ovariectomized (OVX; $\mathrm{n}=8$ ), using a completely randomized design. Ovariectomies were performed when the heifers were between 1 and 3 mo of age. Calves were purchased in groups and assigned randomly to treatments beginning in August, 2000. The last group of calves was purchased in October, 2000. Animals were sacrificed between January and April, 2001, at 6 mo of age. To label proliferating cells, bromodeoxyuridine (BrdU; 5 $\mathrm{mg} / \mathrm{kg}$ BW; Sigma, St. Louis, MO) was injected intravenously $2 \mathrm{~h}$ before sacrifice. At sacrifice, samples of mammary parenchyma were excised from the parenchymal:stromal interface and prepared for histological analysis, as described below. To test the effect of GH on mammary epithelial proliferation and ER $\alpha$ expression, mammary tissues were obtained from a separate study. Five Holstein $\times$ Angus crossbred heifers, aged $6 \mathrm{mo}$, were used for the experiment and were assessed for epithelial proliferation and ER $\alpha$ expression before and after treatment with GH. Each heifer was administered with one injection given i.m. of $500 \mathrm{mg}$ recombinant bST (Posilac; Monsanto, St. Louis, MO). Mammary biopsies were obtained immediately preceding and 1 wk following bST injection, to provide parenchymal tissue for assessment of mammary epithelial proliferation (by incorporation of ${ }^{3} \mathrm{H}$-thymidine to DNA) and ER $\alpha$ expression, as described below. Our assumption in this design is that tissues collected immediately prior to GH treatment are adequate as a control to determine if $\mathrm{GH}$ impacted proliferation or ER $\alpha$ expression. Given that the animals are noncycling, we believe this is a reasonable assumption.

\section{Surgical Procedures}

For ovariectomy, animals assigned to the OVX treatment group were sedated using a combination of intravenously administered xylazine $\mathrm{HCl}$ (The Butler Company, Dublin, OH), $0.1 \mathrm{mg} / \mathrm{kg}$, and butorphanol tartrate (Fort Dodge Animal Health, Fort Dodge, IA), $0.1 \mathrm{mg} /$ $\mathrm{kg}$. Anesthesia was induced using thiopental sodium (Abbott Laboratories, Chicago, IL), $25 \mathrm{mg} / \mathrm{kg}$, IV, and maintained by inhalation of halothane in oxygen. Following induction of anesthesia, the heifers were placed in dorsal recumbency, and the caudo-ventral abdomen and inguinal regions were clipped and aseptically pre- 
pared for surgery. Ovariectomies were performed via a $10-\mathrm{cm}$ caudo-ventral midline celiotomy. The ovaries were isolated, and the ovarian pedicles clamped and ligated using No. 0 polyglycolic acid suture. The ovaries were excised with scissors. The linea alba was closed using a simple continuous pattern of No. 1 polyglycolic acid. The subcutaneous tissues were closed using 2-0 polyglycolic acid suture in a simple continuous pattern, and the skin was closed using 2-0 nylon in a continuous horizontal mattress pattern. Animals were kept in individual pens until they had fully recovered from anesthesia (1 to $2 \mathrm{~h}$ ). Procaine penicillin G (Pfizer, Exton, PA) $22,000 \mathrm{IU} / \mathrm{kg}$ was administered twice daily for $2 \mathrm{~d}$. Biopsies were performed as previously described (Woodward et al., 1993). Briefly, heifers were sedated with Xyalzine (100 mg/ml; Rompum, Mobay Corporation, KA), with $0.2 \mathrm{ml} \mathrm{i.m.} \mathrm{and} 0.1 \mathrm{ml}$ i.v. (jugular vein). The area around the udder was shaved and scrubbed with $70 \%$ ethanol. Skin was cut and blood vessels cauterized using an electroscalpel, and an incision was made $(\sim 4$ $\mathrm{cm}$ ) immediately dorsal and caudal to the teat. Subcutaneous connective tissue was separated using blunt dissection, a piece of mammary parenchymal tissue was removed ( $25 \mathrm{~g})$, and skin was sutured. The subsequent biopsy was performed $7 \mathrm{~d}$ later on one of the previously unsampled glands.

\section{Detection of Estrogen Receptor $\alpha$}

Cellular expression of $\mathrm{ER} \alpha$ was evaluated by immunohistochemistry, as previously described (Capuco et al., 2002). Briefly, tissue samples were fixed for $24 \mathrm{~h}$ in $10 \%$ formalin in PBS ( $\mathrm{pH} 7.4$ ) before they were embedded in paraffin using standard protocols. Five micrometer sections mounted on positively charged slides (Fisher Scientific, Pittsburgh, PA) were deparaffinized in two changes of xylene and rehydrated in a graded series of ethanol to water. Following rehydration, endogenous peroxidases were quenched in $3 \% \mathrm{H}_{2} \mathrm{O}_{2}$. Antigen sites were retrieved by microwaving the slides in

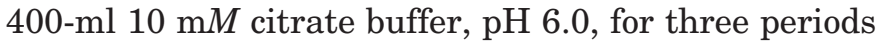
of 5 min each, with 5 min cooling between each period. Following the final microwaving episode, slides were allowed to cool for $30 \mathrm{~min}$. The slides were then washed $3 \times 2$ min in PBS and blocked in 5\% nonimmune goat serum for $30 \mathrm{~min}$. Mouse monoclonal antibovine $\mathrm{ER} \alpha$ (C-311, Santa Cruz Biotechnology Inc., Santa Cruz, CA) was diluted in $1 \%$ nonimmune goat serum to $2 \mu \mathrm{g} / \mathrm{ml}$. Sections were incubated with $100 \mu \mathrm{l}$ of the primary antibody overnight at $4^{\circ} \mathrm{C}$. Subsequently, slides were washed in PBS $(3 \times 2 \mathrm{~min})$, and detection of the primary antibody was performed using Histostain Kit (Zymed Laboratories Inc., San Francisco, CA). Sections were incubated with biotinylated secondary antibody (goat antimouse IgG) for $30 \mathrm{~min}$, washed $(3 \times 2 \mathrm{~min}$ in PBS), and incubated with streptavidin-peroxidase (HRP) conjugate for $10 \mathrm{~min}$. The sections were again washed (3 $\times 2$ min in PBS) before the antibody-HRP complex was visualized by incubation with diaminobenzidine (DAB, Zymed Laboratories Inc., San Francisco, CA) for 5 min. Slides were counterstained in hematoxylin, dehydrated, and mounted with Permount (Fisher Scientific, Pittsburgh, PA). The ER $\alpha$-positive cells were detected by dark brown staining of the cell nucleus. Negative controls were performed by omitting the primary antibody. No background staining was seen in any negative control slides.

\section{Detection of BrdU-Labeled Cells}

Tissues from the ovariectomy experiment were fixed in $10 \%$ formalin in phosphate-buffered saline $(\mathrm{pH} 7.4)$ for $24 \mathrm{~h}$ before being transferred to $70 \%$ ethanol. Samples were then dehydrated through a graded series of ethanol to $100 \%$ ethanol and embedded in Immunobed (Polysciences Inc., Warrington, PA) according to the manufacturer's directions. Sections were cut at $1-\mu \mathrm{m}$ thickness. BrdU-labeled cells were detected as previously described (Ellis et al., 2002). Briefly, sections were hydrated, washed (PBS; $3 \times 2 \mathrm{~min}$ ), and blocked ( $1 \%$ nonimmune goat serum $+1 \%$ BSA; 15 min). Mouse monoclonal anti-BrdU was diluted $1: 100$ to $2 \mu \mathrm{g} / \mathrm{ml}$ in $1 \%$ nonimmune goat serum $+1 \% \mathrm{BSA}$ and incubated with sections for $1 \mathrm{~h}$. Following incubation, slides were washed (PBS; $3 \times 2 \mathrm{~min}$ ) and incubated with gold-conjugated goat antimouse IgG antibodies (Ted Pella Inc., Redding, CA) for $1 \mathrm{~h}$, followed by extensive washing in $\mathrm{ddH}_{2} \mathrm{O}$ and then silver enhancement (Ted Pella, Inc., Redding, CA) for $30 \mathrm{~min}$. Sections were stained for 3 min in $0.5 \%$ azure II and $0.25 \%$ basic fuschin in a $0.5 \%$ Na-borate solution, mounted (Bio-Mount, Ted Pella, Inc., Redding, CA), and photographed. The number of BrdU-labeled cells was determined using digital photographs taken using a $100 \times$ oil-immersion objective lens.

\section{Detection of ${ }^{3} \mathrm{H}$-Thymidine-Labeled Cells}

Tissues from the GH experiment were incubated with ${ }^{3} \mathrm{H}$-thymidine, as previously described (Woodward et al., 1993). Briefly, parenchymal tissue from biopsies were finely diced into small explants ( $\sim 2$ to $3 \mathrm{mg}$ each). Explants $(\sim 200 \mathrm{mg})$ were then incubated in Medium 199 (Sigma, St. Louis, MO), containing $2 \mu \mathrm{Ci}^{3} \mathrm{H}$-thymidine $/ \mathrm{ml}$. Incubations were carried out for $1 \mathrm{~h}$ at $37^{\circ} \mathrm{C}$ and were followed with a wash of $3 \mathrm{ml}$ fresh media without tracer. Subsequently, explants were fixed overnight in $10 \%$ formalin in phosphate buffered saline $\mathrm{pH}$ 7.4) before being transferred to $70 \%$ ethanol. Samples 
were then dehydrated through a graded series of ethanol to $100 \%$ ethanol and embedded in Immunobed (Polysciences, Inc., Warrington, PA), according to the manufacturer's directions. Sections were cut at $1-\mu \mathrm{m}$ thickness. Unstained slides were dipped in emulsion gel (Kodak NTB2, Eastman Kodak, Atlanta, GA) and subsequently developed (Kodak Developer D-19, Eastman Kodak, Atlanta, GA), fixed (Kodak Fixer, Eastman Kodak, and stained in Azure II. Slides were exposed for 2 wk before developing. Photomicrographs were made of sections using a $40 \times$ objective lens, and the proportion of labeled epithelial cells was determined.

\section{Statistics}

Statistics were performed using the SAS statistical package version 8.0 (SAS Inc., Cary, NC 1999). Data obtained from the OVX experiment for the number of BrdU-labeled and $\mathrm{ER} \alpha$-positive cells and were analyzed using a $t$-test to compare means between OVX and control groups. Data obtained from the $\mathrm{GH}$ experiment for ${ }^{3} \mathrm{H}$-thymidine labeled and $\mathrm{ER} \alpha$-positive cells were analyzed using a paired $t$-test to compare means for before and after GH treatment. Differences of $P<0.05$ were considered significant. Data are reported as LS means \pm SEM.

\section{RESULTS}

\section{Effect of Ovariectomy on Epithelial Cell Proliferation and ER $\alpha$ Expression}

Proliferating cells were distinguished by the presence of black granules in the nucleus, indicating incorporation of BrdU into DNA (Figure 1). Proliferation of mammary epithelial cells was decreased 10-fold in OVX heifers compared to control heifers (2.45 vs. $0.25 \% ; P<$ 0.001; Figure 2A) and corresponded to reduced total mammary mass (304 \pm 25 vs. $130 \pm 21 \mathrm{~g}, P<0.001)$. Reduced uterus weight in OVX heifers compared to control heifers $(30.4 \pm 4.5$ vs. $14.5 \pm 3.8 \mathrm{~g}, P<0.05)$ suggests reduced circulating estrogen concentrations.

In addition to changes in overall mammary development and epithelial proliferation, there were several differences in the histology (Figure 3) and abundance of parenchymal tissue in control vs. OVX heifers. While control heifers routinely exhibited more complex branching of epithelial ducts (evidenced by multiple round ductules in histological sections), tissue from most of the OVX animals was rudimentary and consisted of one or two major ducts with limited branching. The degree of ductular complexity appeared to be related to the abundance of parenchymal tissue present, which in turn appeared to be related to timing of the ovariectomy. Parenchyma from animals ovariectomized

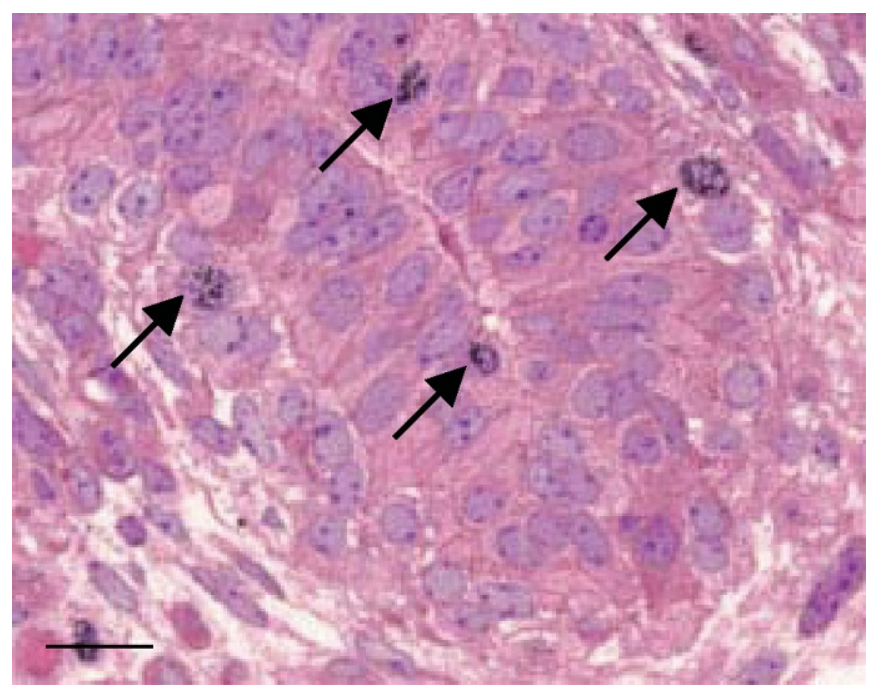

Figure 1. Detection of DNA synthesis in mammary epithelial cells. Arrows indicate BrdU-positive cells (detected by presence of black granules in nucleus). Bar represents $10 \mu \mathrm{m}$. (Color appears onlineonly.)

$<8$ wk of age was almost completely absent and consisted of one or two ductular structures with limited branching. Animals ovariectomized after $\sim 8$ wk of age had substantially more total parenchymal tissue. These tissues also had more complex branching and many terminal ductular units (TDU) characteristic of actively growing ducts. The greater number of arborescent structures observed in the mammary gland of control heifers likely reflects areas of active growth. Conversely, tissue from OVX heifers likely lacked similar active growth centers and hence appeared as a rudimentary, less complex, ductular structure. Our perception was that the mechanistic growth processes were the same in both groups of animals but that active growth was inhibited in OVX animals, possibly because of reduced $\mathrm{E}$ concentration and subsequent loss of proliferative stimulus. In both OVX and control heifers, the mammary epithelial cells can be classified as falling into one of three categories: lumenal (one surface of the cell in contact with the lumen), basal (one surface of the cell in contact with the basal membrane), and embedded (no contact with lumen or basal membrane).

As expected from previous observations (Capuco et al., 2002), expression of $\mathrm{ER} \alpha$ was confined to mammary epithelial cells (Figure 4). The greatest number of ER $\alpha$ positive cells were within the embedded layer of epithelial cells, although $\mathrm{ER} \alpha$-positive lumenal and basal cells were also noted. The effect of ovariectomy on the proportion of $\mathrm{ER} \alpha$-labeled cells is shown in Figure 2B. The proportion of $\mathrm{ER} \alpha$-positive cells was significantly higher in OVX compared to intact animals $(46.7 \% \pm 2.4$ vs. $36.1 \% \pm 2.2 ; P<0.05)$. 


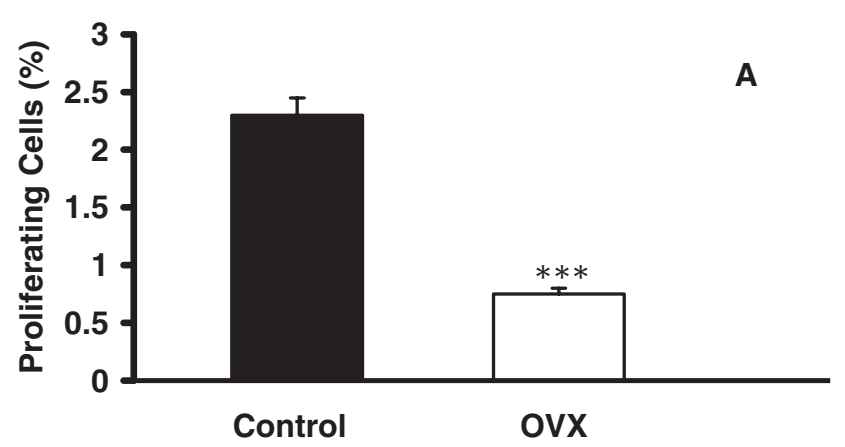

B

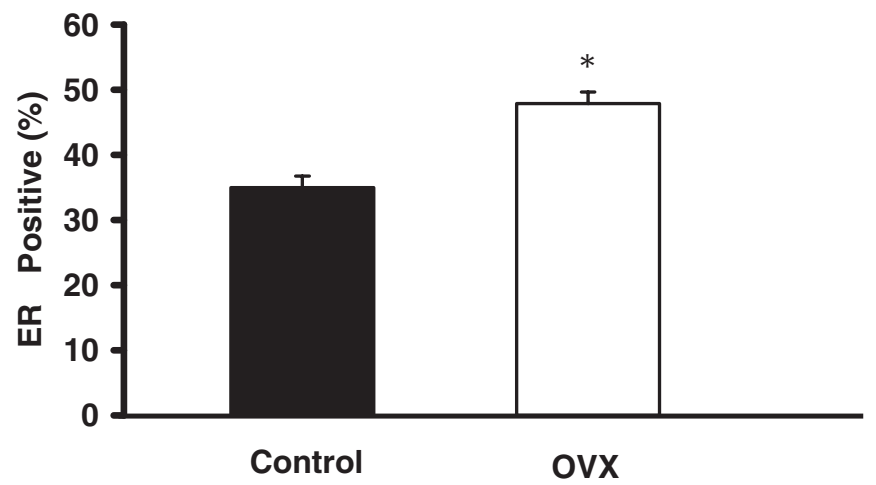

Figure 2. A) Proliferation of mammary epithelial cells as measured by incorporation of BrdU into DNA. Number of proliferating cells are expressed as a percentage of total epithelial cells. B) Effect of ovariectomy on $\mathrm{ER} \alpha$. Positively labeled epithelial cells are expressed as percentage of total epithelial cells. ${ }^{* * *} P<0.001 ;{ }^{*} P<0.05$ compared with controls.

\section{Effect of GH on Cell Proliferation and ER $\alpha$ Expression}

The effect of GH on proliferation of mammary epithelial cells is shown in Figure 5A. Treatment of heifers with GH resulted in a sixfold increase in epithelial cell proliferation $(0.62 \% \pm 0.02$ vs. $3.92 \% \pm 0.87 ; P<0.01)$. Although we hypothesized that GH would increase the proportion of $\mathrm{ER} \alpha$-positive cells within the mammary gland, the proportion of $\mathrm{ER} \alpha$ labeling was not affected by the GH treatment (Figure $5 \mathrm{~B} ; 38.7 \pm 0.94 \%$ vs. 40.4 $\pm 0.84 \% ; P>0.1$ ). As in the first experiment, ER $\alpha$ was confined to mammary epithelial cells and was most commonly present in the embedded layer, although some lumenal and basal cells did express the ER $\alpha$.

\section{DISCUSSION}

Although knock-out mouse models have demonstrated that ER $\alpha$ is essential for proper postnatal mammary development in mice (Korach, 1994), hormonal regulation of $\mathrm{ER} \alpha$ expression and the role of $\mathrm{ER} \alpha$ in regulating mammary epithelial proliferation within the bovine mammary gland is undefined. In this study, we determined the effects of ovariectomy and $\mathrm{GH}$ on proliferation of mammary epithelial cells and corresponding expression of $\mathrm{ER} \alpha$ in prepubertal heifers. Ovariectomy before 3 mo of age dramatically reduced mammary growth in prepubertal heifers at $6 \mathrm{mo}$ of age. One possible explanation for the decrease in mammary weight and epithelial proliferation is a reduction of systemic estrogen concentrations. This is supported by a significant decrease in uterus weight from OVX animals. However, it is also possible that our observations are not related to changes in circulating estrogen, but to a

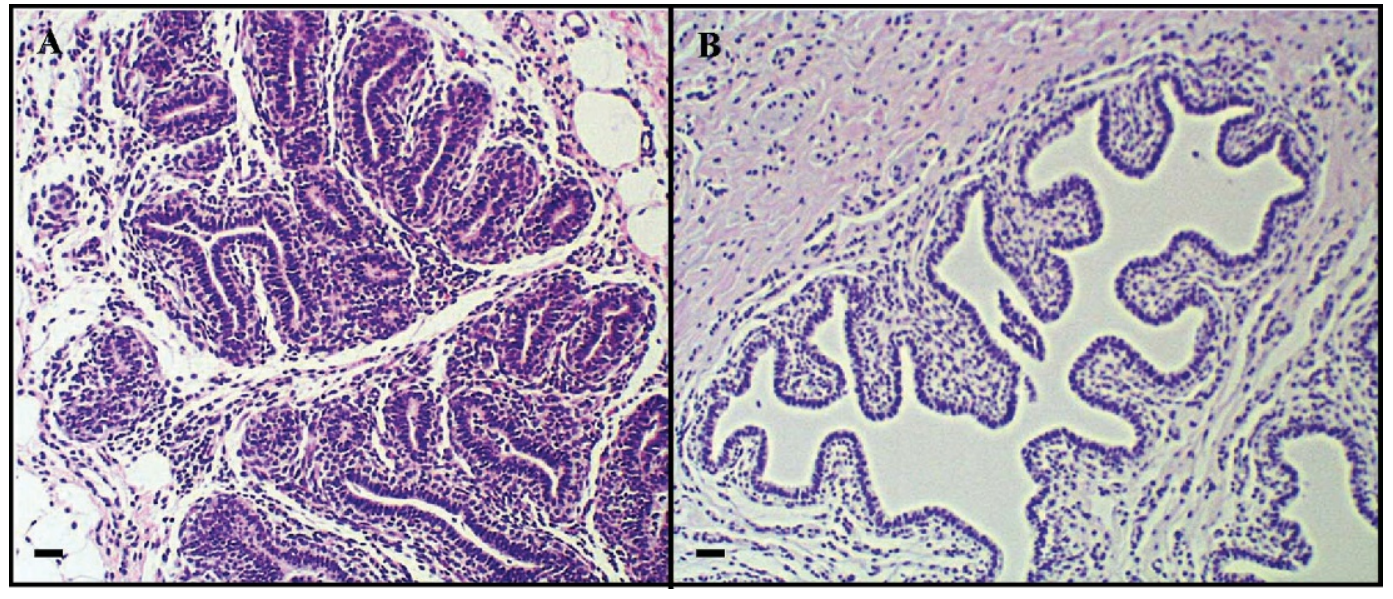

Figure 3. Representative images of hematoxylin and eosin staining of parenchymal tissue from intact (A) and ovariectomized (B) heifers. Note presence of complex branching structures in the intact heifer compared with a singular ductular structure in the ovariectomized heifer. Bars represent $20 \mu \mathrm{m}$. (Color appears online-only.) 


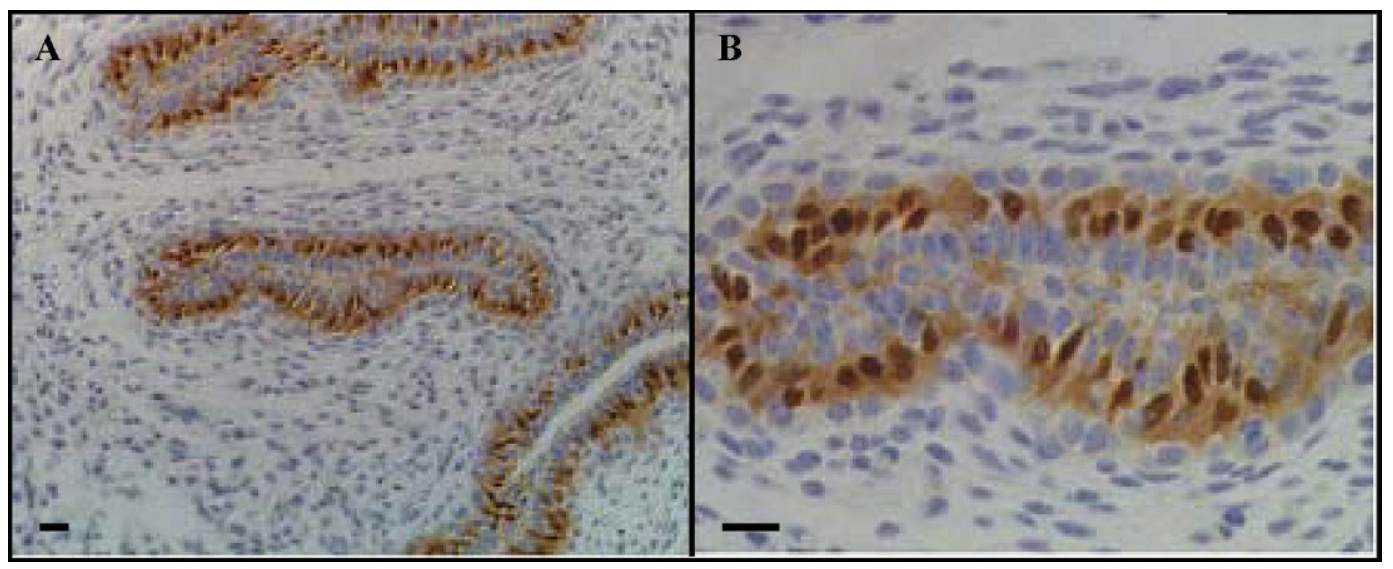

Figure 4. Expression of ER $\alpha$ in mammary epithelial cells. A) low magnification of three ductular structures from a prepubertal heifer. Note presence of ER $\alpha$ in epithelial cells only (brown stained nuclei). B) Higher magnification of duct similar to that shown in A. ER $\alpha$ is present primarily in the embedded layer of epithelial cells. Bars represent $10 \mu \mathrm{m}$. (Color appears online only.)

change in synthesis or secretion of other ovarian regulated compounds. In a previous study, ovariectomy of prepubertal calves resulted in only a small $(0.1 \mathrm{pg} / \mathrm{ml})$ decrease in systemic estrogen concentrations (Purup et al., 1993).

Whether the dramatic changes in mammary development and proliferation seen in this trial are due solely to a reduction in serum estrogen concentration is not clear. Interestingly, the mammary glands of animals ovariectomized before $\sim 6 \mathrm{wk}$ of age appeared to be more severely affected by the ovariectomy than animals ovariectomized between 8 and 12 wk of age. Animals ovariectomized before $6 \mathrm{wk}$ of age did not develop any additional epithelial tissue, and at 6 mo of age, parenchymal tissue from an individual gland approximated an area of about $3 \times 5 \times 3 \mathrm{~mm}$. On the other hand, animals ovariectomized after $6 \mathrm{wk}$ of age continued to develop epithelial tissue, so that at 6 mo of age, mammary parenchyma was a substantially greater mass than it was at the time of ovariectomy. In other words, before 6 wk of age, ovariectomy appeared to completely terminate mammary development, but after $6 \mathrm{wk}$ of age, ovariectomy appeared to hinder, but not completely inhibit, mammary development. This may be related to previous observations of mammary epithelial cell proliferation in prepubertal heifers (Ellis and Capuco, 2002), in which proliferation was greater at 2 mo of age than at 5 or 8 mo of age. Possibly, there is a critical period between birth and 2 mo of age during which removal of ovarian stimulation of epithelial proliferation is more severe than after 2 mo of age.

The pattern of $\operatorname{ER} \alpha$ expression within the bovine mammary gland is similar to that recently reported (Capuco et al., 2002). ER $\alpha$ was confined to mammary epithelial cells, and within the epithelial tissue, it was present primarily in the embedded layer of cells. A small proportion of lumenal and basal epithelial cells were also positive for ER $\alpha$. Staining was mostly within the nucleus of epithelial cells, although cytoplasmic staining was occasionally evident in some cells. Our observation of increased ER $\alpha$ expression in OVX heifers may be explained by two possibilities. First, systemic estrogen concentrations may be reduced (as implied by the decreased uterus weight for OVX heifers), thus leading to up-regulation of $\mathrm{ER} \alpha$ expression due to loss of negative feedback mechanisms. Alternatively, the change in $\mathrm{ER} \alpha$ may be related to changes in epithelial cell populations. In a previous study (Ellis and Capuco, 2002), the proportion of light staining cells (putatively mammary stem cells) decreased between 2 and 5 mo of age, while the proportion of darkly staining cells increased. This observation implies that epithelial cells may undergo a transition from light to dark staining as the mammary epithelium matures. Possibly, epithelial cells also become ER $\alpha$ positive as they mature. This is supported by observations that proliferating cells are $\mathrm{ER} \alpha$ negative (Capuco et al., 2002) and that lightly staining cells make up $90 \%$ of proliferating cells (Ellis and Capuco, 2002). In contrast, dark cells comprise $30 \%$ of the total epithelial cell population but only $7 \%$ of proliferating cells. Possibly, the increased proportion of $\mathrm{ER} \alpha$-positive cells in OVX animals is due to a smaller population of immature, proliferative, $\mathrm{ER} \alpha$-negative epithelial cells compared with intact controls.

As previously reported (Berry et al., 2001), short-term treatment with GH stimulated a significant increase in mammary epithelial proliferation. However, the mechanisms by which GH stimulates mammary development and epithelial proliferation are not fully understood. Accumulated evidence strongly suggests that lo- 

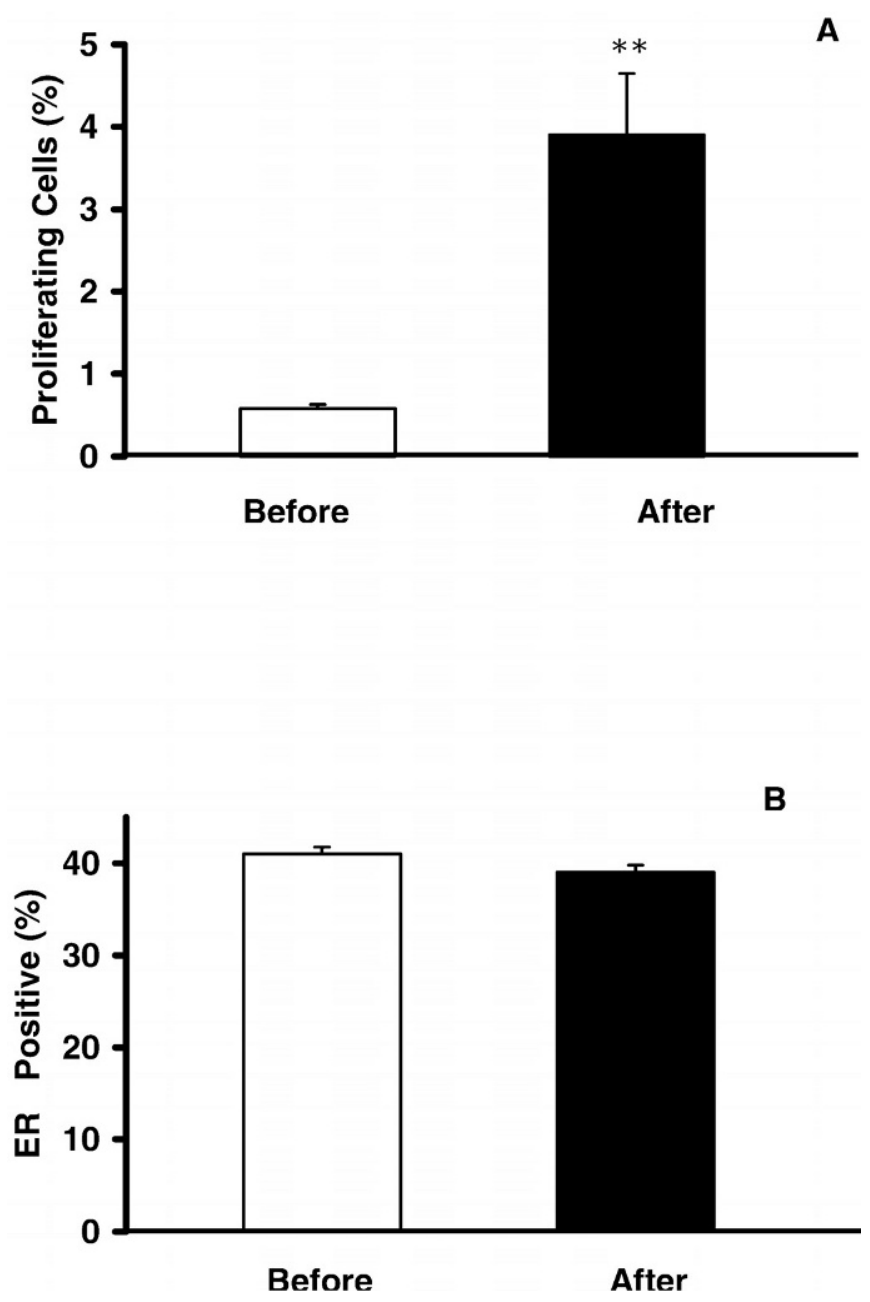

Figure 5. A) Effect of growth hormone on proliferation of mammary epithelial cells as measured by incorporation of ${ }^{3} \mathrm{H}$-thymidine into DNA. Number of proliferating cells are expressed as a percentage of total epithelial cells. B) Effect of growth hormone on ER $\alpha$. Positively labeled epithelial cells are expressed as percent of total epithelial cells. $* * P<0.01$ compared with controls.

cally derived IGF-I mediates the proliferative effects of GH within the mammary gland (Kleinberg, 1997; Akers et al., 2000). However, recent reports demonstrate presence of GH receptor mRNA and protein in the bovine mammary gland (Sinowatz et al., 2000; Plath-Gabler et al., 2001) suggesting that GH may have direct, IGFI independent effects on bovine mammogenesis. For example, raising heifers on a high rate of gain impairs mammary development and uncouples the GH-IGF-I axis: serum GH is reduced, but serum IGF-I concentration is increased (Sejrsen et al., 2000; Weber et al., 2000). Thus, reduced mammary development resulting from high feeding level is correlated with decreased serum concentrations of GH but with increased serum concentrations of IGF-I. Changes in locally produced
IGF-I or IGFBP also do not fully explain this effect, implying that the mechanism of $\mathrm{GH}$ action within the mammary gland is more complex than mere mediation by IGF-I and IGFBP. In rodents, administration of GH increased expression of ER $\alpha$ mRNA and protein within the mammary gland (Feldman et al., 1999). Possibly, one role of GH within the mammary gland is to enhance the effects of estrogen via increased expression of ER $\alpha$.

However, in contrast to these reports, we observed that GH had no effect on the proportion of $\mathrm{ER} \alpha$-positive cells within the mammary gland of prepubertal heifers, even though we observed a dramatic ( sixfold) increase in epithelial cell proliferation. Therefore, in the present experiment, proportion of $\mathrm{ER} \alpha$ labeling did not appear to be related to $\mathrm{GH}$-induced proliferation within the mammary gland. Consequently, GH regulation of $\mathrm{ER} \alpha$ expression may differ in the bovine compared with rodent models. Alternatively, GH may have increased the number of functionally active ER $\alpha$-positive cells without increasing the proportion of mammary epithelial cells expressing the receptor. Also, assessment of percent positive staining for the receptor does not evaluate the level of receptor expression per cell. It may be that the relative expression among positive-staining cells is physiologically important.

\section{CONCLUSIONS}

In summary, we demonstrate that ovariectomy of prepubertal heifers decreased proliferation of mammary epithelial cells but increased the proportion of ER $\alpha$ positive cells. This may be attributed to decreased circulating $\mathrm{E}$ concentration and a removal of feedback inhibition or to previous observations that proliferating epithelial cells are negative for $\mathrm{ER} \alpha$ (Capuco et al., 2002). GH stimulated mammary epithelial proliferation, but no changes in the proportion of $\mathrm{ER} \alpha$-positive cells were found. Therefore, it appears unlikely that GH enhances the effects of $\mathrm{E}$ through up-regulation of $\mathrm{ER} \alpha$ in prepubertal heifers. Furthermore, our observations that mammary development was more severely affected in heifers ovariectomized before 6 wk of age imply that there is a critical period of ovarian stimulation during the first 2 mo of age.

\section{ACKNOWLEDGMENTS}

Funding for this research was provided by a NRIUSDA grant \# 98-9803664 (to R. M. Akers) and by a NRI-CGP USDA postdoctoral grant \# 00-03236 (to S. E. Ellis). S. D. K. Berry was the recipient of the Frank Sydenham and C. Alma Baker scholarships for graduate study in agriculture. 


\section{REFERENCES}

Akers, R. M., T. B. McFadden, S. Purup, M. Vestergaard, K. Sejrsen, and A. V. Capuco. 2000. Local IGF-I axis in peripubertal ruminant mammary development. J. Mam. Gland Biol. Neo. 5:43-51.

Berry, S. D., T. B. McFadden, R. E. Pearson, and R. M. Akers. 2001. A local increase in the mammary IGF-1:IGFBP-3 ratio mediates the mammogenic effects of estrogen and growth hormone. Domest. Anim. Endocrinol. 21:39-53.

Capuco, A. V., S. Ellis, D. L. Wood, R. M. Akers, and W. Garrett. 2002. Postnatal mammary ductal growth: three-dimensional imaging of cell proliferation, effects of estrogen treatment, and expression of steroid receptors in prepubertal calves. Tissue Cell 34:9-20.

Couse, J. F., and K. S. Korach. 1999. Estrogen receptor null mice: What have we learned and where will they lead us? Endocr. Rev. 20:358-417.

Ellis, S., and A. V. Capuco. 2002. Cell proliferation in bovine mammary epithelium: identification of the primary proliferative cell population. Tissue Cell 34:21-28.

Feldman, M., W. Ruan, I. Tappin, R. Wieczorek, and D. L. Kleinberg. 1999. The effect of GH on estrogen receptor expression in the rat mammary gland. J. Endocrinol. 163:515-522.

Haslam, S. Z. 1989. The ontogeny of mouse mammary gland responsiveness to ovarian steroid hormones. Endocrinology 125:27662772 .

Haslam, S. Z., and L. J. Counterman. 1991. Mammary stroma modulates hormonal responsiveness of mammary epithelium in vivo in the mouse. Endocrinology 129:2017-2023.

Jarvinen, T., M. Pelto-Huikko, K. Holli, and J. Isola. 2000. Estrogen receptor $\alpha$ is coexpressd with ER $\alpha$ and PR and associated with nodal status, grade and proliferation rate in breast cancer. Am. J. Pathol. 156:29-35.

Kleinberg, D. L. 1997. Early mammary development: growth hormone and IGF-I. J. Mam. Gland Biol. Neopl. 2:49-57.

Korach, K. S. 1994. Insights from the study of animals lacking functional estrogen receptor. Science 266:1524-1527.

Kuiper, C., E. Enmark, M. Pelto-Huikko, S. Nilsson, and J. Gustafsson. 1996. Cloning of a novel receptor expressed in rat prostate and ovary. Proc. Natl. Acad. Sci. USA 93:5925-5930.

Lammers, B. P., A. J. Heinrichs, and R. S. Kensinger. 1999. The effects of accelerated growth rates and estrogen implants in prepubertal holstein heifers on estimates of mammary development and subsequent reproduction and milk production. J. Dairy Sci. 82:1753-1764.

Mohamed, M. K., and A. A. Abdel-Rahman. 2000. Effect of longterm ovariectomy and estrogen replacement on the expression of estrogen receptor gene in female rats. Eur. J. Endocrinol. 142:307-314.

Mueller, S. O., J. A. Clark, P. H. Myers, and K. S. Korach. 2002. Mammary Gland Development in Adult Mice Requires Epithelial and Stromal Estrogen Receptor $\alpha$. Endocrinology 143:2357-2365.

Plath-Gabler, A., C. Gabler, F. Sinowatz, B. Berisha, and D. Schams. 2001. The expression of the IGF family and GH receptor in the bovine mammary gland. J. Endocrinol. 168:39-48.

Purup, S., K. Sejrsen, J. Foldager, and R. M. Akers. 1993. Effect of Exogenous Bovine Growth Hormone and Ovariectomy on Prepubertal Mammary Growth, Serum Hormones and Acute in- Vitro Proliferative Response of Mammary Explants from Holstein Heifers. J Endocrinol. 139:19-26.

Rosser, M., L. Chorich, E. Howard, P. Zamorano, and C. Mahibrown. 1993. Changes in rat uterine estrogen receptor messenger ribonucleic acid levels during estrogen- and progesterone-induced estrogen receptor depletion and subsequent replenishment. Biol. Reprod. 48:89-98.

Saji, S., E. Jensen, S. Nilsson, T. Rylander, M. Warner, and J.-A. Gustafsson. 1999. Estrogen receptors $\alpha$ and $\beta$ in the rodent mammary gland. Proc. Natl. Acad. Sci. USA 97:337-342.

Sejrsen, K., S. Purup, M. Vestergaard, and J. Foldager. 2000. High body weight gain and reduced bovine mammary growth: physiological basis and implications for milk yield potential. Domest. Anim. Endocrinol. 19:93-104.

Sinha, Y. N., and H. A. Tucker. 1968. Mammary development and pituitary prolactin level of heifers from birth through puberty and during the estrous cycle. J. Dairy Sci. 52:507-512.

Sinowatz, F., D. Schams, S. Kolle, A. Plath, D. Lincoln, and M. J. Waters. 2000. Cellular localisation of GH receptor in the bovine mammary gland during mammogenesis, lactation and involution. J. Endocrinol. 166:503-510.

Topper, Y. J., and C. S. Freeman. 1980. Multiple hormone interactions in the developmental biology of the mammary gland. Physiol. Rev. 60:1049-1106.

Weber, M. S., S. Purup, M. Vestergaard, R. M. Akers, and K. Sejrsen. 2000. Regulation of local synthesis of insulin-like growth factorI and binding proteins in mammary tissue. J. Dairy Sci. 83:30-37.

Woodward, T. L., W. E. Beal, and R. M. Akers. 1993. Cell interactions in initiation of mammary epithelial proliferation by oestradiol and progesterone in prepubertal heifers. J. Endocrinol. 136:149-157.

Zeps, N., J. M. Bentel, J. M. Papadimitriou, M. F. D’Antuono, and H. J. Dawkins. 1998. Estrogen receptor-negative epithelial cells in mouse mammary gland development and growth. Differentiation 62:221-226. 